\title{
Sustainability Impact Assessments as Inputs and as Interpretative Aids in International Investment Law
}

\author{
Markus Gehring, Sean Stephenson, Marie-Claire Cordonier Segger
}

\section{Introduction}

Over the past 25 years the international regime for protection of foreign investments, alongside cross border flows of capital, have substantially grown in terms of the number of treaties, with nearly 3000 investment agreements currently in force, and international arbitrations under those treaties. Over the same time concern for sustainable development, climate change, and greener economies, defined here as the "environmental regime," has also substantially increased. The growth in both regimes has caused increased intersection between the investment and the environment regimes substantively, procedurally and institutionally. This intersection has become more prevalent as cross-border investments accelerate and intensify through increasingly fast and frequent investment mechanisms with an ability to bolster and aggravate environmental issues and concerns.

Impact assessments on trade and investment agreements or investment treaties are one tool to measure the effects and mitigate the tensions between investment and sustainable development, and climate change issues. As noted by the European Commission "it is a process that prepares evidence for political decision-makers on the advantages and disadvantages of possible policy options by assessing their potential impacts." Although various types of impact assessments exist for specific issues, in the EU sustainability impact assessments (SIAs) integrate economic, environmental social, and more recently human rights considerations and assess the overall impact of a decision. EU SIA will be the focus on this paper. This has been the predominate means of analysis on trade agreements since the inception of impact assessments for trade agreements and now also investment.

SIAs have been performed on all major "multilateral, regional or bilateral [trade] negotiations" since $1999 .{ }^{2}$ This practice has not changed since 2009 when the Treaty of Lisbon entered into force and Foreign Direct Investment (FDI) was brought under the exclusive external trade competence of the EU. ${ }^{3}$ SIA's are currently performed through third parties and analyze the predicted impact of an agreement prior to the conclusion of a specific treaty. In this regard, as SIAs may address the trade/ investment environment, social and human rights nexus first as an input into the treaty negotiation process. Here, it

\footnotetext{
${ }^{1}$ European Commission, Impact Assessment Guidelines, 15 January, 2009 at 4 available at: http://ec.europa.eu/smart-regulation/impact/commission_guidelines/docs/iag_2009_en.pdf ${ }^{2}$ European Commission, Trade, Sustainability Impact Assessment available at http://ec.europa.eu/trade/policy/policy-making/analysis/sustainability-impact-assessments/ ${ }^{3}$ European Union Treaty of Lisbon Amending the Treaty on European Union and the Treaty Establishing the European Community 13 December 2007, 2007/C306/01; Article 207(1) of the TFEU includes FDI as part of the common commercial policy (CPP). Article 3(1) states the CPP is the exclusive competence of the EU.
} 
is also argued that in the investment context SIAs may have a continuum of influence, having the potential to be used in the interpretation of an investment chapter or agreement in the event of an investment dispute. Hence, second SIAs and the Commission response position paper may act as interpretive aids. This paper focuses specifically on the impact relating to the investment-environment nexus.

SIAs can provide important inputs in negotiations. Specifically, in relation to investment and environment, if SIAs are performed with a specific focus on environmental issues, they can aid in predicting sectors and industries that will benefit from investment related to adaptation or mitigation of anthropogenic climate change. At the same time, they can identify tensions that may result as a result of an increasing liberal trade and investment framework, such as when investment may be made in sectors adverse to mitigating anthropogenic changes in climate. SIA's may also predict where crucial features such as knowledge sharing in crucial technologies to adapt and mitigate climate the effects of climate change, while allowing sectors and industries to leap frog over long development through advanced research and practice may occur.

But SIAs are not just relevant for the negotiation process. As an interpretive aid, the SIA and the unique Commission position paper made public in response to an SIA may also be relevant to the interpretation of the treaty. This paper is intended to highlight the potential relevance of SIAs and the corresponding Commission response in relation to dispute settlement, by analyzing their interpretive value SIAs are given minimal legal attention. In analyzing the SIA and response, this paper argues that the European Commission's Response position paper to a final SIA report may be used to interpret a trade or investment treaty as part of a treaties' travaux préparatoires or the circumstances of the treaties conclusion. Such a public and direct response to the specific aspects identified within a treaty could provide valuable documentation relating to a treaty interpretation argument on the basis of Article 32 of the Vienna Convention on the Laws of Treaties.

Part 2 of this paper reviews the development and legal status of SIAs in the EU. It also reviews the substantive and procedural elements of SIA's in the EU that have developed through practice status. Part 3 looks at two distinct case studies from recent EU trade negotiations, and in particular how these SIAs have addressed sustainable development, and climate change issues. Specifically, it looks at the SIAs undertaken in relation to the EU-Canada Comprehensive Economic Trade Agreement, an agreement between the EU and a single state, and the EU- African Caribbean Pacific (ACP) Economic Partnership Agreements (EPAs), an agreement between various states without geographic proximity. It then provides critiques and recommendations for SIAs relating to its legal structure and specifically from a sustainable development and climate change perspective, which, if implemented may positively affect the investment-environment nexus as an input and interpretive aid. Part 4 highlights how an SIA and the corresponding Commission response may be useful to dispute settlement as an interpretive aid under a given international investment treaty. 


\section{Sustainability Impact Assessments of Trade and Investment Treaties in the EU}

In order to properly understand how SIAs function as inputs and how they could function as interpretative aids in an arbitration it is crucial to first review the SIA legal status, requirements and process. These aspects influence how an SIA is performed and what is covered by an SIA.

Moving forward for future investment agreements in the EU it should in particular be recalled that according to Articles 206 and 207 of the the Lisbon Treaty on the Functioning of the European Union ("TFEU"), FDI has now become an exclusive competence of the EU as part of the common commercial policy. ${ }^{4}$ The rationale behind this change rests on the ground that, in a world of globalized transfers of goods and capital, and as a consequence of the EU common commercial policy, the investment policy of European member states should be coordinated at European level. ${ }^{5}$ Before the entry into force of the TFEU, member states concluded more than 1000 bilateral agreements relating to investment with third countries, related in part or in full to foreign direct investment. These include Bilateral Investment Treaties ("BITs") which provide, inter alia, guarantees on the conditions of investment in Member States and in third countries, in the form of specific commitments binding under international law.Pursuant to the new policy, the EU BITs need to be replaced by a new frame of modern EU investment treaties consistent with horizontal EU policy goals, and this has to be done within a reasonable time frame. ${ }^{6}$ SIAs should be performed on any new agreements.

Specifically, in relation to investment Articles 206 and 207 TFEU mention only FDI as an exclusive competence of the EU but the exact extend of this competence remains as a point of discussion between the EU and its Member States. The CJEU has defined FDIs based on three criteria: (a) a long-lasting investment; (b) representing at least $10 \%$ of the affiliated company's equity capital/shares; and (c) providing the investor with managerial control over the affiliated company's operations. ${ }^{7}$ In other words, FDI is usually construed to include any foreign investment which serves to establish lasting and direct links with the undertaking to which capital is made available, in order to carry out an economic activity. ${ }^{8}$ That decision is expected to have implications on what elements

\footnotetext{
${ }^{4}$ European Parliament, Report on the Proposal for a Regulation of the European Parliament and of the Council Establishing Transitional Arrangements for Bilateral Investment Agreements Between Member States and Third Countries (COM(2010)0344 - C7-0172/2010 - 2010/0197(COD)), dated 14 April 2011, at p. 17 available at http://www.europarl.europa.eu/sides/getDoc.do?pubRef=//EP//NONSGML+REPORT+A7-2011-0148+0+DOC+PDF+V0//EN. 
relating to investment are included within the EU's competence, and will accordingly an impact on subsequent SIAs. However, if the CJEU maintains this definition in the upcoming Opinion X/2015 on the EU-Singapore FTA and that investment, including dispute resolution mechanism form part of this competence, this would mean that the EU competence will be comparatively wide and thus the insights to be gained from SIA widely applicable in Europe. ${ }^{9}$

\subsection{Development \& Legal Status of SIA's in the EU}

The recent history of trade, investment and environment law stems from both increased environmental concern and higher frequency in cross border movement of goods and services. The creation and implementation of SIAs in the EU were reactionary. Sustainability impact assessments of trade treaties in the EU did not begin until 1999 in anticipation for the WTO Millennium Round of negotiations. ${ }^{10}$ Many civil society groups had started to focused on the trade and environment nexus and mobilized significant protests, especially in Seattle. Member States also prompted the Directorate-General Trade to integrate ex ante sustainable development considerations into trade agreements. A process was created similar to the UNEP integrated assessments and the US Environmental Reviews. After several pilot studies, DG Trade created and decided to externally commission impact assessments for trade, which it called Sustainability Impact Assessments. ${ }^{11}$

With the SIA for trade having been initially created, in the lead up to the 2002 World Summit on Sustainable Development in Johannesburg the European Council committed to implementing sustainable development and to establish a tool for sustainable impact assessment. ${ }^{12}$ The European Council agreed to" a strategy for sustainable development which completes the Union's political commitment to economic and social renewal, adds a third, environmental dimension to the Lisbon strategy and establishes a new approach to policy making." ${ }^{13}$ The Council further agreed that the

\footnotetext{
${ }^{9}$ The specific questions submitted to the Court are "Does the Union have the requisite competence to sign and conclude alone the Free Trade Agreement with Singapore? More specifically: Which provisions of the agreement fall within the Unions exclusive competence? Which provisions of the agreement fall within the Unions shared competence? and Is there any provision of the agreement that falls within the exclusive competence of Member States?" In relation to investment, the authors believe that the definition of investment will necessarily be discussed. See http://eur-lex.europa.eu/legal-

content/EN/TXT/?uri=CELEX\%3A62015CU0002

${ }^{10}$ European Commission, Trade, "Sustainability Impact Assessments" available at: http://ec.europa.eu/trade/policy/policy-making/analysis/sustainability-impact-assessments/; Markus Gehring, Impact Assessment and Investment - A Sustainable Approach for the European Union? (2011 CISDL Working Paper) at p. 29-30.

${ }^{11}$ European Commission, External Trade, Handbook for Sustainability Impact Assessment, March 2006, at forward available at http://trade.ec.europa.eu/doclib/docs/2006/march/tradoc_127974.pdf

${ }^{12}$ European Council, Goteborg European Council, Presidency Conclusions, SN 200/1/01 REV 1 available at: http://ec.europa.eu/smart-regulation/impact/background/docs/goteborg_concl_en.pdf.

${ }^{13}$ European Council, Goteborg European Council, Presidency Conclusions, at para 20.
} 
"arrangements for implementing this strategy will be developed by the Council." 14 This commitment resulted in the development of an SIA methodology which began in 2003. ${ }^{15}$

Slightly before that point, in 2002, the Commission's position on impact assessment was clarified in a 2002 Communication on Impact Assessments. ${ }^{16}$ This Communication stated that SIAs should be applied to all major EU initiatives and would replace all existing separate impact assessments mechanism including business impact assessment, gender assessment, environmental assessment, small and medium enterprises assessment, trade impact assessment, regulatory impact assessment. ${ }^{17}$ The Communication noted that tailor-made impact assessments assessing one aspect would often be partial[ly] looking only at certain sets of impacts." Such an approach did not adequately or fully assess the potential trade-offs of a given decision. ${ }^{18}$ In short, it was determined that the SIA would provide a more holistic view of the impacts of decisions. The Communication also clarified the need to implement SIAs across a large number of policies and decisions in the EU.

In opting for the SIA approach the EU notably differed from other states in analyzing the impact of trade agreement such as the environmental review performed on US trade agreements which only analyses impacts in the US, as opposed to the trade partner in question and possibly other parties, and exclusively analyses environmental impacts. The EU SIA aims to analyses social, economic, and environmental impacts on the EU and its partner country. It was subsequently broaden to include human rights impact analysis. While the instruments both share common elements such as the participation of civil society to analyze the potential impacts and the robustness of the respective draft studies.

Despite this development any requirement to perform SIAs remain in legal limbo. In strict legal terms, the Communication on SIAs only has the status of a policy guideline. There has been no further legislation or legal developments to bolster the legal status of SIAs. SIA's are therefore applied to trade and investment agreements solely on the basis of a political commitment. ${ }^{19}$ The lack of a legally embedded SIA requirement and binding process for SIAs ensures that SIAs contain elements of uncertainty as to

${ }^{14}$ ibid.

${ }^{15}$ Handbook for Sustainability Impact Assessment, supra note 11 at 6.

${ }^{16}$ Commission of European Communities, Communication from the Commission on Impact Assessment, June 5, 2002, COM(2002) 276 available at: http://eur-

lex.europa.eu/LexUriServ/LexUriServ.do?uri=COM:2002:0276:FIN:EN:PDF

${ }^{17}$ Commission of European Communities, Communication from the Commission on Impact Assessment, supra note 18 at 1 and 3.

${ }^{18}$ Commission of European Communities, Communication from the Commission on Impact Assessment, supra note 18 at 3 . Here, it should be noted that as of 2012 all SIAs now include an "analysis of the potential human rights impacts of the trade agreement under negotiation." This done pursuant to Article 21 of the Treaty on European Union. Handbook for trade sustainability impact assessment, 2nd edition, April 2016 [SIA Handbook] available at: http://trade.ec.europa.eu/doclib/docs/2016/april/tradoc_154464.PDF

${ }^{19}$ Indeed, the 2002 Communication makes it clear that "Impact assessment is an aid to decision-making, not a substitute for political judgment." Commission of European Communities, Communication from the Commission on Impact Assessment, supra note 18 at 3. 
scope of what SIAs should be covering and how SIAs should be implemented and followed through.

In February 2004 DG Trade began a consultation process to codify the methodology for the SIAs and a decision was made, at least within the Commission, to observe the outcomes of an SIA. ${ }^{20}$ The most recent version of the SIA Handbook "sets out the main characteristics, objectives and principles of the new generation of SIAs, set against the new international framework for sustainable development which follows the adoption of the 2030 Agenda for Sustainable Development, including the Sustainable Development Goals (SDGs)." ${ }^{21}$ Certain impact assessment principles are now even set out the recent 2015 EU Policy "Trade for All" where it is noted that the Commission will "undertake an in-depth analysis of the possible effects of new FTAs on LDCs in sustainability impact assessments, with a view to designing flanking measures when necessary." 22

Prior to the EU obtaining competence over investment in 2009 investment competence was held by member states. Hence, bilateral investment agreements that were concluded by member states between 1999 and 2009 did not undergo the EU SIA process. However, investment has previously been considered in SIAs. At the end of 2015, over 22 SIAs had been completed with several more ongoing, some of which include investment analysis.

For example, there are several instances where a SIA has evaluated the impact from investment liberalization. Indeed, the SIA of Mercosur Negotiations - Final Overview SIA Final Report even develops an elaborate indicator system for investment liberalization. It contains an evaluation of the proposed investment agreement on the economic indicators of real income, fixed capital formation, and employment. On the social side, it contains evaluations on indicators like poverty, health, education, and equity as well as, on the environmental side, on indicators like biodiversity, environmental quality and natural resources. While the SIA had to remain somewhat general, since it was analysing all Mercosur countries plus Chile, the assessors remarked: "The inclusion of investment agreement provisions in the EU Mercosur Association Agreement is expected to generate economic gains for European investors in Mercosur. It is not expected to impact on the inflow of FDI to the EU. There are no significant social or environmental impacts expected in the EU Member States." 23

\footnotetext{
${ }^{20}$ DG Trade, SIA Methodology, A Consultation paper, February 2004 online: http://trade.ec.europa.eu/doclib/docs/2004/february/tradoc_115875.pdf; Markus W. Gehring, \& MarieClaire Cordonier Segger, "Sustainable Development through Process in World Trade Law" in Sustainable Development in World Trade Law, M. Gehring \& M.C. Cordonier Segger, eds. (London: Kluwer Law International, 2005) at p. 212.

${ }^{21}$ SIA Handbook, supra note 20 at 4.

${ }^{22}$ European Commission, Trade for All: Towards a more responsible trade and investment policy, October 2015 available at: http://trade.ec.europa.eu/doclib/docs/2015/october/tradoc_153846.pdf.

${ }^{23}$ See Manchester University, SIA of Mercosur Negotiations - Final Overview SIA Final Report, at 81.
} 
Some SIAs also highlighted the positive influence that increased investment in the right sectors can have. As such, the SIA on the EU-Mediterranean FTA concluded that increased water use could be reversed with increased investment:

"The optimization of water use is a central issue in EMCs as well as Morocco. The effects of the EMFTA are strongest for producers of agricultural commodities such as Egypt and Syria. Livestock production, particularly for beef, is also a heavy water consumer. As for Morocco, food security concerns may still drive Egypt and Syria to cultivate cereals, and water valuation issues are similar. There is a need for investment and training in new agricultural practices and irrigation technologies. Preferential technology transfer arrangements and more liberalized trade regimes in relevant environmental goods would have a significant environmental benefit." 24

In sum, despite SIA's being applied to all the EU's major multilateral, regional or bilateral trade negotiations since 1999 it cannot yet be argued that these assessments could be said to be required as a legal obligation. However, nonetheless trade SIA's have developed and are applied to EU trade negotiations consistently.

\subsection{Substantive \& Procedural Elements of SIAs}

Although there is no specific legal requirement for SIAs (the Commission carries out internal Impact Assessments as to whether to engage in any regulatory project), substantive and procedural elements for SIAs have been developed. ${ }^{25}$ These elements are derived from the Commission's past actions when performing SIAs for trade agreements and appear to be equally applied to IIAs under the EUs new investment competence. ${ }^{26}$ The substantive elements of an SIA focus on the potential impact of investment. Substantive elements for SIAs may be broken down into both phases and key elements.

\section{SIA Phases}

SIAs follow a pre-determined process to ultimately provide suggestions of types of improvements which may enhance the overall impact on sustainable development of the investment agreement as an SIA for trade. ${ }^{27}$ The SIA process begins within 6 months

\footnotetext{
${ }^{24}$ Institute for Development Policy and Management (IDPM), University of Manchester, The European Union's Sustainability Impact Assessment (SIA) Study of the Euro-Mediterranean Free Trade Area (EMFTA) at 36.

${ }^{25}$ See, SIA Handbook, supra note 20 for a review of the substantive and procedural steps; See also, European Commission, Guidelines on Impact Assessment, available at: http://ec.europa.eu/smartregulation/guidelines/ug_chap3_en.htm.

${ }^{26}$ For example, an SIA was carried out for the EU-Vietnam agreement and the Commission position paper was published post 2009. More recently, the SIA on TTIP and several other agreements have occurred entirely after the EU assumed competence over investment including analysis on investment impacts. ${ }^{27}$ See Markus W. Gehring, \& Marie-Claire Cordonier Segger, "Sustainable Development through Process in World Trade Law" in Sustainable Development in World Trade Law, M. Gehring \& M.C. Cordonier Segger, eds. (London: Kluwer Law International, 2005) at 211.
} 
of the start of the negotiations ${ }^{28}$ and are based on the principles of integration, independence, evidence based decision making, transparency, participation and proportionality. ${ }^{29}$

As with trade agreements scoping would comprise the first phase. After the tender and Terms of Reference, the first step is an inception report which lays out the methodology to be used. ${ }^{30}$ Initial screening and scoping occur at this stage to identify elements which will be negotiated and have a significant impact and key sectors to analyse. In relation to sustainable development, climate change both the terms of reference and scoping are crucial phases. This phase sets key requirements for the overall analysis.

The second phase includes an initial sustainability assessment in the form of an interim report. This analysis for an SIA includes a baseline assessment, an economic assessment, a social assessment, environmental, and human rights assessment of the key treaty provisions based on indicators determined at the initial phase that is specific to the parties and agreement being negotiated. A further substantive aspect is the assessment of the potential impact of the IIA on third party states.

The third phase includes the preparation and dissemination of the final report where specific recommendations may be made, and a general review of outcomes and findings are made. The Commission then sets out in a position paper "how the SIA findings have or will contribute to decision making." 31 The fourth phase of the SIA process, the mitigation and enhancement analysis is prepared after the conclusions of the negotiations. The purpose of which would be to outline the impacts of the policy recommendations on the final outcome of the agreement. ${ }^{32}$ The Commission performs an additional economic assessment of the negotiated outcomes of a trade and investment agreements for the European Parliament and Council. ${ }^{33}$ Here, it should be noted that such an analysis is limited to an economic assessment.

An additional fifth phase has yet to be applied to an SIA assessment for a trade agreement. Although in the new EU Directive 2014/52/EU on Impact assessments of projects, the monitoring and verification to monitor the actual impact will become mandatory. Transposed to SIAs, this could for example mean analysing the implementation of the agreement or verifying compliance. Although ex post evaluations are noted in the recent 2 nd edition of the SIA Handbook and have been performed on certain EU trade and investment agreements, they are not mandatory. ${ }^{34}$

\footnotetext{
${ }^{28}$ SIA Handbook, supra note 20, at 11.

${ }^{29}$ ibid. at 6.

${ }^{30}$ ibid. at 12 .

31 ibid.at 13.

${ }^{32}$ M. Gehring \& M.C. Cordonier Segger, “Overcoming Obstacles with Opportunities: Trade and Investment Agreements for Sustainable Development” in S. Schill, C. Tams \& R. Hoffmann, International Investment Law and Development: Bridging the Gap (London: Edward Elgar, 2015 forthcoming) at 10.

${ }^{33}$ SIA Handbook, supra note 20 , at 8.

${ }^{34}$ ibid.
} 


\section{Key SIA Substantive Elements}

In addition to phases, key elements of SIAs include baselines, economic, social, and environmental assessments, and the effects on third parties. All analysis must establish a baseline to determine the existing economic, social, environmental and human rights conditions of a negotiating party from which the potential impacts of an IIA may be assessed.

Environmental assessment should include an analysis of the environmental policy space and the potential effect on environmental regulatory regimes. This is of crucial importance in an area such as IIAs which have received a reputation for 'regulatory chill' which some state have stopped the adoption of some environmental laws or policies for fear of investment arbitration. ${ }^{35}$ Analysing the potential restrictions of the environmental policy space through the new IIA would certainly constitute helpful advice for policy makers and could play an important role when an SIA response is used in interpretation. This of course would be in addition to any specific environmental impacts that an IIA could potentially have on distinct areas such as biodiversity or climate change. Further, as noted in the 2016 SIA handbook an environmental analysis should also include "in principle" an analysis "on aspects such as climate change, including the most important types of greenhouse gases (GHG) emission, air quality, use of energy, water quality and resources, land use, soil quality, waste and waste management, biodiversity, ecosystem services and protected areas" while also identifying how the agreement may green the economy, utilize resource efficiency, and promote sustainable consumption and production. ${ }^{36}$

Economic assessments should include an assessment of the potential impact of substantive FDI restrictions and liberalisation as well as an assessment of the potential impact an IIA will have on the Parties economic policy. In terms of substantive restrictions and liberalizing provisions the assessment of the impact of such provisions should be done on a sectoral basis so that the economic impact of these provisions can be specifically detailed for each sector, while taking note of all liberalising or ratching provisions.

The economic assessment should also review the potential impact on economic policy space. Here, the assessment should be mindful of any restrictions in regulatory flexibility an IIA may place on a party to implement public policy that would have an economic, social or environmental benefit. In addition, the substantive economic assessment should also review impact of any dispute settlement provision that may be included with an agreement such as access to investor-state dispute settlement, domestic courts or other forms of dispute settlement.

\footnotetext{
${ }^{35}$ See e.g. Corporate Observatory Europe, Polluters Paradise, December 2015, available at: http://corporateeurope.org/sites/default/files/pollutersparadise.pdf. Here, it should be noted that while such critiques have been alleged by certain civil society groups, such allegations are rarely, if ever, substantiated with examples of where such concerns have occurred.

${ }^{36}$ SIA Handbook, supra note 20, at 23.
} 
Social assessments should also take into the account the potential impact on restrictions or reductions in a state's ability to implement social policies. This can include "regulatory chill," where the government does not enact new 'socially desirable' laws and regulations because of possible legal ramification. Other social welfare indicators such as displacement of workers, decency and quality of work, and inequality of wages may also be analysed to determine the potential social impact of an IIA.

As of 2012 human rights assessments have been included within the SIA, The inclusion of a human rights analysis places a specific emphasis on human rights impacts of trade and investment agreements. As noted in the SIA Handbook consultants analysing human rights impacts will also be guided by the Guidelines on the analysis of the human rights impacts in impact assessment for trade-related policy initiatives. ${ }^{37}$ The human rights component of the analysis is supposed to identify the specific human rights likely to be impacted, analyse the extent of the impact on such a right and identify the individuals or groups likely to be affected.

With respect to substantive provisions one unconventional and controversial aspect is that SIAs also take into account the possible effect on third parties to the agreement. Externalities such as the effects on key trading partners with the negotiating state not included in the negotiations should be taken into account. For example, in CETA the SIA for investment included sub-sections for the US and Mexico for the economic, social and environmental assessments as well as the indicators that informed those sections. ${ }^{38}$ Without taking into account the effect on third parties during the negotiations the overall result desired may be undermined by actions of third parties.

\section{Key SIA Procedural Elements}

On a procedural level, certain key elements should be integrated into all SIA processes. One key procedural element is the requirement of participation. This includes adequate public participation with stakeholders. Public participation has been identified as key element of the SIA process. ${ }^{39}$ The public participation procedures developed for FTA's have taken the form of stakeholder meetings in both the EU and in the negotiating parties' home state, as well as inputs that can be accessed online. Online access to public comment, or other widely available public access, is critical so that the public participation process is inclusive and accessible. Stakeholder consultations and consultations with experts may place focus on issues overlooked within investment negotiations. ${ }^{40}$

\footnotetext{
${ }^{37}$ SIA Handbook, supra note 20, at 21.

${ }^{38}$ See generally Final Report, A Trade SIA Relating to the Negotiation of a Comprehensive Economic Trade Agreement (CETA) Between the EU and Canada, June, 2011, Trade/B3/B06 [CETA Final Report] available at http://trade.ec.europa.eu/doclib/docs/2011/september/tradoc_148201.pdf.

${ }^{39}$ M. Gehring \& M.C. Cordonier Segger, “Overcoming Obstacles with Opportunities: Trade and Investment Agreements for Sustainable Development” supra note 35, at 7.

${ }^{40}$ ibid
} 
Here, however, it should be noted that the proper scrutiny and weight should be attributed public consultation responses. For example, the recent TTIP public consultation relating to investment provided a large number of online submissions leading to a substantial shift in EU investment policy as articulated in the 2015 Trade for All policy and subsequent investment court system under the TTIP and adoption in the CETA and the EU-Vietnam agreement. However, such an about face policy shift has led some commentators state that the concerns raised in the public consultations were baseless and could not be substantiated. ${ }^{41}$ While such an issue does not diminish the crucial importance of public participation and consultation these concerns must be factored into the analysis of the public participation.

Further, participation of other agencies or departments may also prove to be useful in providing expertise for specific areas, particularly in relation to environmental and social aspects.

With the EU new competence over investment this framework for SIAs, developed in the context of trade and investment agreements, could be directly implemented for IIAs negotiated by the EU in the future. While the substantive and procedural elements in themselves do not directly focus on sustainable development, climate change, and green economy this sets out the basic framework for analysis which can address these issues specifically.

On a procedural level investigating the impacts of an agreement on trading partners at times becomes difficult. Unfortunately, research collaboration with trading partners is not always reciprocal. In studies undertaken in relation to agreements with the MERCOSUR and Mediterranean regions, cooperation was fruitful; but the study on the EC-Cooperation Council for the Arab States of the Gulf negotiations did not unfold as envisioned. ${ }^{42}$ Public participation in these expert studies varied from extensive debates and consultations to merely an administered website. As one private consultancy noted in their study: "The NGO world did not show a big interest in the topic [despite efforts to engage with them, $\mathrm{NGO}[\mathrm{s}]$ from the GCC have not even replied to our requests to get their view [and] input." $" 43$ Despite the lack of a binding legal framework under which SIA is considered, arguably an impediment to its further progress, there is a de facto requirement for the Commission to observe outcomes.

As inputs, SIAs therefore have a well developed practice. SIAs are be conducted for all parts of the new EU trade competence, which since 2009 includes foreign direct investment, or at least certain elements of it, which is set to be defined through the CJEU. This process thus result in higher availability of data and findings which is to be used in

\footnotetext{
${ }^{41}$ Alison Ross, "Schwebel criticizes EU act of "appeasement," Global Arbitration Review, May 24, 2016.

${ }^{42}$ See Price Waterhouse Coopers, Sustainability Impact Assessment (SIA) of the negotiations of the trade agreement between the European Community and the Countries of the Cooperation Council for the Arab States of the Gulf $(G C C)$ (Brussels: PWC, 2004), online: <http://www.sia-gcc.org/gcc/download/sia_ftagcc_final_reportmay2004.pdf>.

${ }^{43}$ ibid. at 36 .
} 
the negotiations of trade and investment treaties. The SIA process and analysis is highlighted here through case studies.

\section{EU SIA Case Studies}

In practice SIAs are performed by outside consultants with the results being submitted to the Commission. The SIA process has recently been completed in the Canada-EU CETA negotiations, and the EU- African Caribbean Pacific (ACP) Economic Partnership Agreements (EPAs). This highlights that SIAs are performed on trade agreements in very different negotiating contexts. The case studies highlight the analysis relating to investment in differing contexts demonstrating that the SIA process may be directly applied to any future EU investment agreement. The case studies further highlight how SIA may take into account the core pillars of sustainable development and climate change.

\subsection{The Canada-EU Comprehensive Economic and Trade Agreement}

The CETA negotiations were officially launched on May 6, 2009 at the CanadaEU Summit in Prague. ${ }^{44}$ This was preceded by a joint Canada-EU study completed in 2008 on the benefits of a trade agreement. ${ }^{45}$ At the time of writing the CETA has yet to be ratified, however it has been called a "generational game changer" on the basis of the depth and scope of agreement. ${ }^{46}$

On January 22, 2010, the EU released its public tender to perform the SIA including the Terms of Reference. ${ }^{47}$ The Terms of Reference set out the parameters for the analysis to be undertaken by the third party consultant outlining the basis for performing the SIA and specific sectors and issues to be considered. The SIA for CETA began in July 2010 and was comprised of three phases. The first phase included information gathering, the preparation of analytical tools, and flagging potential issues. During this phase, an inception report, detailing key sustainability issues to be considered and the methodologies to be employed for the SIA process was published in October 2009 and was made available to the Steering Committee Meeting and Civil Society in 2010. The second phase analysis was presented in an interim report which was comprised

\footnotetext{
${ }^{44}$ CETA Final Report, supra note 41 at 24.

${ }^{45}$ See Canada/ EU, "Assessing the Costs and Benefits of a Closer EU-Canada Economic Partnership: A Joint Study by the European Commission and the Government of Canada, 2008, available at: http://trade.ec.europa.eu/doclib/docs/2008/october/tradoc_141032.pdf.

${ }^{46}$ C. Sosnow, P. Kirby, S. Stephenson, "The Canada-Europe Comprehensive Free Trade Agreement and the Mining Sector: Key Issues and Opportunities" 9 Global Trade and Customs Journal (2014) Global Trade and Customs Journal, Issue 6, pp. 253-259 at p. 253(?).

${ }^{47}$ European Commission, Invitation to tender for a service contract to provide a Trade Sustainability Impact Assessment (Trade SIA) relating to the negotiation of a Comprehensive Economic and Trade Agreement (CETA) between the EU and Canada, January 22, 2010, available at: http://trade.ec.europa.eu/doclib/docs/2010/august/tradoc_146399.pdf.
} 
of an interim quantitative and qualitative impact assessment. ${ }^{48}$ These findings were presented to stakeholders, and submitted to the Steering Committee in late October 2010. The third phase incorporated further stakeholder feedback, revised economic modeling, impact assessments and developed policy recommendations for negotiators. The SIA was concluded with a final report released in June 2011. This was also presented to civil society shortly before that date in March $2011 .^{49}$

The Final Report entitled "A Trade SIA Relating to the Negotiation of a Comprehensive Economic Trade Agreement (CETA) Between the EU and Canada "provides a comprehensive assessment of the potential impacts of trade liberalisation under CETA." 50 The analysis assesses the impact of the agreement in three main sectors of agriculture, processed agricultural products and fisheries, ${ }^{51}$ industrial products, ${ }^{52}$ and the service sector, ${ }^{53} 16$ sub-sectors and analyzes an additional seven cross-cutting issues. $^{54}$ For each sub-sector and cross-cutting issue an economic, social and environmental assessment was performed identifying the potential of impacts of CETA. In addition for each sector and for certain cross-cutting issues the CETA SIA assessed the impact of CETA on the US, Mexico and a number of developing countries and the EU OCTs of Saint-Pierre Miquelon and Greenland. ${ }^{55}$ While the SIA focused on the trade aspects, investment liberalisation was also discussed in the specific sectors and in a standalone chapter

Specifically, the investment section, under the cross-cutting issues heading, looks how the agreement would promote investment and the investor state dispute settlement mechanism. The investment section contains an analysis of the predicted economic, social, and environmental impacts of CETA, with each section including specific indicators on which the analysis is premised. The definition of investment in the NAFTA was used to undertake the analysis. ${ }^{56}$ The section also contains an analysis on the impact of CETA on investment in the US and Mexico.

From an economic standpoint the investment section concludes that the CETA as a whole and through its investment chapter will have a positive effect on trade, intangible business linkages and may increase GDP in both Canada and the EU. For Canada, the SIA predicts a reinforcement to existing investment trends with the majority for

\footnotetext{
${ }^{48}$ See Final Interim Report, Trade SIA Relating to the Negotiation of a Comprehensive Economic Trade Agreement (CETA) Between the EU and Canada, December 2010 Trade 10/B3/B06 available at: http://trade.ec.europa.eu/doclib/docs/2011/february/tradoc_147500.pdf .

${ }^{49}$ CETA Final Report supra note 41 at 26.

${ }^{50}$ ibid. at 14.

${ }^{51}$ The agriculture, processed agricultural products and fisheries assessment included specific analysis on grains and oilseed, beef and pork, dairy, beverages, and fisheries.

${ }^{52}$ The industrial product assessments included assessments of mining and metal manufacturing, oil and petroleum products, coal, forest-based industries, automotive and other transport equipment, and textiles.

${ }^{53}$ The service sector assessments included assessments on transportation services, telecom services, financial services, and business services.

${ }^{54}$ The cross cutting issues analyzed by the SIA include government procurement, intellectual property rights, investment, trade facilitation, labour mobility, free circulation of goods, and competition policy.

${ }^{55}$ CETA Final Report p. 102-120, 198-205, 255-256.

${ }^{56}$ ibid. at footnote 961.
} 
investment flows going toward financial, energy and mining sectors. Further increased investment flows may also appear if barriers in certain sectors are also lifted. Similarly, the SIA predicts a positive flow of FDI into the EU, however on a smaller scale. ${ }^{57}$ The Final Report also concludes that it is doubtful that an investor-state dispute settlement mechanism would create a net/ overall "sustainability benefit for the EU and/ or Canada." 58

\section{Climate Change}

In relation to climate change greenhouse gas emissions formed part of the criteria for environmental quality. ${ }^{59}$ It should be noted that an analysis on the impact of climate change was directly included in the Terms of Reference which stated:

The Contractor shall carry out a detailed analysis of different types of external environmental costs of the future CETA, including the impact of trade liberalisation on the most important types of greenhouse gas (GHG) emissions in the EU, in Canada and in the rest of the world. For this purpose, the Contractor should decompose the GHG effect into scale effects (as a result of increased output), composition effects (as a result of shifts in the relative weight of sectors) and possibly technique effects (as a result of productivity increases that can be attributed to the CETA). The analysis should cover at least the emissions of the most energy-intensive sectors and of primary energy producing sectors. ${ }^{60}$

The consequence of the inclusion of climate change in the Terms of Reference for external consultants is directly viewed in the Final Report which contains 117 references to greenhouse gas emissions, a number which includes references to baseline GHG emissions- emissions that are not in reference to impact. Although climate change issues may be further raised and honed through the inception report and civil society the inclusion in the Terms of Reference specifically ensures that a third party consultant will address the trade, investment and climate nexus.

In relation to the investment, the Final Report includes only two indicators in its environment related analysis; the first "Biodiversity, water usage, and contamination, toxic contaminants and effulents, air pollution and GHG emissions" and the second "Environmental policy space, institutional and regulatory environment." The Final Report notes that increased investment in the oil sands and mining sectors may result in "an increase in production capacity that would in turn lead to impacts on capital stocks, use of bio-diverse areas, water use and contamination, toxic contaminants and effluents, and air pollution and GHG emissions." ${ }^{61}$ On the other hand, the SIA also notes that increased investment may also be directed into green technology which may have a positive effect in both Canada and the EU. ${ }^{62}$ Depending on its provisions, the Final Report notes that CETA may also influence policy space, although the Final Report notes that the "available evidence does not convincingly suggest that investor-state provisions

\footnotetext{
${ }^{57}$ ibid. at 337

${ }^{58}$ ibid. at 337

${ }^{59}$ Ibid. at 29.

${ }^{60}$ supra note 49 at 12.

${ }^{61}$ ibid at 338 .

${ }^{62}$ ibid at 338 .
} 
in NAFTA to date have created significant reductions of the type of environmental policy space relevant to this SIA." ${ }^{63}$ Within the analysis on investment although greenhouse gas emissions formed part of an indicator the analysis was brief and simply referred to the sectoral analysis in other parts of the agreement.

More generally, in the analysis of the entire agreement the model employed to conduct the analysis allows for GHGs to be broken down sectorially. ${ }^{64}$ The SIA details both positive and negative impacts on greenhouse gases in both Canada and the EU. In Canada sectors and industries that will increase their greenhouse gas emissions include the transport sector, ${ }^{65}$ cattle and swine production, ${ }^{66}$ and industrial products, ${ }^{67}$ minor increases in mining and metal manufacturing sectors. ${ }^{68}$ Specifically in terms of investment the Final Report states that "it is unclear how much CETA would increase investment in the oil sands and mining sectors, and if investment does not particularly increase then the directly related environmental impacts therein would clearly be lessened."69

Conversely, in Canada certain sectors and industries are expected to not be affected or are predicted to decrease emissions. In relation to energy industries the Final Report notes that "[t]he impact of trade liberalisation arising from the CETA is estimated to have a neutral impact on GHG emissions by contributing in a negligible way to a further increase of oil production in Canada." ${ }^{70}$ Additionally, in Canada there is not expected to be an increase in emissions in forestry productions ${ }^{71}$ with a marginal increase expected in the EU. ${ }^{72}$ In relation to car production in Canada the Final Report notes:

"Ongoing improvements in energy intensity are likely to offset in part the increase in GHG emissions caused by the expansion in production in this sector. This is predictable in light of the major investments made in the past two years in the U.S. and Canadian automotive sector to increase productivity and competitiveness." 73

\footnotetext{
${ }^{63} \mathrm{ibid}$. at 387.

${ }^{64}$ ibid. at 33 .

${ }^{65} \mathrm{ibid}$. at 18.

${ }^{66}$ ibid at 93. For example for Canada " Under full liberalisation, the E3MG model predicts a $0.75 \%$ to $0.76 \%$ rise in methane emissions by 2020 and a $0.61 \%$ to $0.72 \%$ rise in NOx emissions by 2020 . Emissions associated with transportation can be expected to rise with the increase in shipment of agricultural commodities across the Atlantic between Canada and the EU as a result of CETA." On the other hand, the report notes that as the EU has a mature cattle and pork emissions are set to slightly decrease, whereas an increase in dairy production could lead to increased emissions. Additionally, manure management could potentially increase ghgs in the EU.

${ }^{67}$ ibid at 123 .

68 ibid. at 148. "Although the metal manufacturing sector has reduced its GHG emissions intensity over time, the lack of GHG regulations or carbon pricing mechanisms in Canada significantly reduces incentives to improve energy intensity or reduce emissions. The introduction of a mandatory carbon pricing mechanism could more than offset the impacts of any growth on this sector's GHG emissions."

${ }^{69} \mathrm{ibid}$ at 339.

${ }^{70}$ ibid at 161 .

${ }^{71} \mathrm{ibid}$ at 179.

${ }^{72} \mathrm{ibid}$ at 180 .

${ }^{73}$ ibid at 189.
} 
In relation to services there is an overall prediction that greenhouse gas emissions will rise. ${ }^{74}$ The "greatest impact is likely to arise in the transportation services as significant growth in maritime transport across the Atlantic is expected." 75 However, the report notes a potential offset if "EU investment in Canada supports a shift from road to maritime transportation, particularly through the development of Canada's short-sea shipping industry."76 The Final Report also notes that:

"To the degree that expansion in the services sector attracts resources away from more environmentally harmful sectors (such as in the manufacturing and extractive industries), the environmental impact from the CETA could be mitigated over the longterm." 77

In the EU, minor emissions increases are expected in forestry production. ${ }^{78}$ The Final Report also notes "Increased EU investment in the Canadian transportation sector could further increase GHG emissions. However, if EU investment leads to the introduction of new fuel efficient technologies it could contribute to offsetting this increase, or even reducing emissions. Emissions reduction measures such as a shift to natural gas for freight transportation or new energy efficiency standards could also offset this growth in emissions." 79 Specifically in relation to services in the transport sectors "are likely to be marginal for rail transportation but significant for the road, air and marine transport sectors." 80

Many sectors are predicted to have relatively no change in emissions or to benefit from CETA by reducing emissions. Automotive-related greenhouse gases emissions are predicted to be minor with "the only noteworthy impact on sectoral output is in the production of other transport equipment, with estimates projecting a minor reduction of the sector's GHG emissions." ${ }^{81}$ Similarly, in mining and metal manufacturing sectors no significant effect is expected with a minor reduction in the EU production of non-ferrous metals. ${ }^{82}$ CETA is also predicted to have a negligible impact on oil production and causal emissions in the EU with emissions predicted to slightly rise through an increase in refinery production. ${ }^{83}$ None of the findings specifically highlight the regulatory space in this field but the expectation as to the impact can provide a useful indication for future interpretation.

\section{Commission Response}

The Commission has not yet published a position paper on the CETA SIA. However, from the CETA text published the SIA appears to have impacted the

\footnotetext{
${ }^{74}$ ibid at 208.

${ }^{75} \mathrm{ibid}$ at 208

${ }^{76} \mathrm{ibid}$ at 208 .

${ }^{77} \mathrm{ibid}$ at 208 .

${ }^{78}$ ibid at 180 .

${ }^{79} \mathrm{ibid}$ at 227.

${ }^{80} \mathrm{ibid}$ at 226.

${ }^{81}$ ibid. at 190.

${ }^{82} \mathrm{ibid}$. at 149.

${ }^{83} \mathrm{ibid}$. at 161 .
} 
negotiations. For example, the final SIA report includes an overarching issues section which recommends a Trade and Sustainable Development chapter within CETA, which would establish a monitoring body and include a section on trade and labor which would commit to the International Labor Organization's Core Labour Standards and Decent Work Agenda. ${ }^{84}$ CETA does include a Trade and Sustainable development chapter. Including this chapter was a first for Canada which has developed the practice of including labour and environmental agreements outside of the actual trade agreement, as side agreements. Further, the Trade and Environment Chapter provides a forum for regulatory harmonization between the EU as recommended ${ }^{85}$ Furthermore the scrubbed CETA text now establishes an investment court system. Although the SIA did not recommend an investor-state dispute settlement system it does not appear that the SIA was the driving reason for such a change. Rather, that change was a result of a public consultation and several internal EU debates.

\subsection{EU- African Caribbean Pacific (ACP) Economic Partnership Agreements (EPAs)}

SIAs have also been performed on economic partnerships between groupings of states as demonstrated by the EU- African Caribbean Pacific (ACP) Economic Partnership Agreements (EPA). This SIA covered the 77 counties from Western Africa, Central Africa, Southern and Eastern Africa, the Caribbean and the Pacific. ${ }^{86}$ In 2000 the EU and the ACP signed the Cotonou Agreement, ${ }^{87}$ the basis of EU-ACP development cooperation, which established the framework for ACP-EU relations. ${ }^{88}$ The central objectives of ACP-EU are stated in article 19 of the Cotonou Agreement and include poverty reduction/ eradication, sustainable development, and progressive integration of the ACP countries into the world economy. ${ }^{89}$ The rationale for these agreements differed from that of CETA as it was specifically focused on sustainable development, a principle stated in the Cotonou Agreement. The Cotonou Agreement provided for EPAs to be negotiated from September 2002 until December 2007..$^{90}$

\footnotetext{
${ }^{84}$ ibid at 432-434.

${ }^{85}$ Canada, Global Affairs, CETA “Final Text (Feb 2016)" available at: http://trade.ec.europa.eu/doclib/docs/2016/february/tradoc_154329.pdf

${ }^{86}$ Qualified Preliminary EU-ACP SIA of the EPAs: Phase One, Final Report, February, 2004 at p.2 http://trade.ec.europa.eu/doclib/docs/2005/january/tradoc_121195.pdf; These states include member states of the Economic Community of West African States (ECOWAS)+Mauritania, the Economic and Monetary Community of Central Africa (CEMAC + Sao Time and Principe, the South African Development Community (SADC) minus South Africa, the Common Market for Eastern and Southern Africa (COMESA) minus Egypt + Somalia and the Pacific Island Countries Trade Agreement.

${ }^{87}$ Partnership Agreement between the members of the African, Caribbean and Pacific Group of States of the one part and the European Community and its Member States, of the other part, (Cotonou Agreement) 23 June 200, L317/5 available at http://eur-lex.europa.eu/legalcontent/EN/TXT/PDF/?uri=CELEX:22000A1215(01)\&from=EN

${ }^{88}$ Plan and Schedule for CARIFORUM, EC Negotiation of an Economic Partnership Agreement April 2004, available at: http://www.sice.oas.org/TPD/CAR_EU/Negotiations/Plan_neg_e.pdf.

${ }^{89}$ Cotonou Agreement, supra note 90 at article 19.

${ }^{90}$ ibid.
} 
The SIA took place over four years, beginning in late 2002, which coincided with the opening of the EPA negotiations, with the final report being published in May, 2007. ${ }^{91}$ The SIA did not come from a direct tender based on Terms of Reference set by the Commission but was described in outcome documents from regional consultations. ${ }^{92}$ The SIA took into account that six EPAs are being negotiated with six different ACP regions and cover a wide range of issues and sectors over four phases. ${ }^{93}$ For example, CARIFORUM, representing Caribbean states, had a specific plan and schedule for negotiating an $\mathrm{EPA}^{94}$ but formed part of the larger EU-ACP SIA. ${ }^{95}$

The phases for the SIA included:

- Phase I: a preliminary overall SIA and two pilot regional SIAs for West Africa and the Caribbean.

- Phase II focused on three specific sectors in three of the six regions: agro industry in West Africa, tourism in the Caribbean and fisheries in the Pacific.

- Phase III focused on three sectors and issues in the remaining three regions: financial services in Central Africa, horticulture in East and South Africa and rules of origin in Southern Africa.

- Phase IV completed the SIA, bringing together the results of the previous phases, drawing up detailed conclusions and recommendations for stakeholders and policy makers across the regions and summarising the dissemination process and stakeholder engagement. ${ }^{96}$

\footnotetext{
${ }^{91}$ Position Paper Sustainability Impact Assessment of EU-ACP Economic Partnership Agreements, 16 November 2007 at p. 1 and 2 available at http://trade.ec.europa.eu/doclib/docs/2007/november/tradoc_136958.pdf.

92 See e.g. "Sustainability Impact Assessment (SIA) of the ACP-EU Economic Partnership Agreements, Caribbean Consultation Seminar, November 11-13, 2003 available at: http://trade.ec.europa.eu/doclib/docs/2005/january/tradoc 121203.pdf; Etude de l'Impact sur le Development Durable des Accordes de Partenariat Economique ACP-UE (SIA ACP-UE), Seminaire de Consultation de la Societe Civile, du secteur Prive et des Collectivites locales d'Afrique de l'Ouest, available at http://trade.ec.europa.eu/doclib/docs/2005/january/tradoc_121206.pdf.

93 PricewaterhouseCoopers, "Sustainability Impact Assessment of the EU-ACP Economic Partnership Agreements- key findings, recommendations and lessons learned", Paris, PricewaterhouseCoopers, May 2007, At p. 9 [EPA Final Report] available at: http://trade.ec.europa.eu/doclib/docs/2007/june/tradoc_134879.pdf; Position Paper Sustainability Impact Assessment of EU-ACP Economic Partnership Agreements, 16 November 2007 at p. 1 and 2 available http://trade.ec.europa.eu/doclib/docs/2007/november/tradoc_136958.pdf.

94 See: Plan and Schedule for CARIFORUM, EC Negotiation of an Economic Partnership Agreement, supra note 91.

${ }^{95}$ For the purposes of the EU negotiations Caribbean Forum of ACP States (CARIFORUM) represents the regional configuration of the following countries- Antigua and Barbuda, The Bahamas, Barbados, Belize, Commonwealth of Dominica, Dominican Republic, Grenada, Guyana, Haiti, Jamaica, St. Kitts and Nevis, Saint Lucia, St. Vincent and the Grenadines, Suriname, and Trinidad and Tobago. These countries include developing countries, least developed countries (LDCs), landlocked countries and small island developing states - face special challenges related to development. Thirty-eight ACP countries fall under the United Nations classification of LDC. Five LDCs are located in the Pacific region, one (Haiti) is in the Caribbean region and the remaining 32 are located in Africa.

96 Position Paper Sustainability Impact Assessment of EU-ACP Economic Partnership Agreements, 16 November 2007 at p. 2 available http://trade.ec.europa.eu/doclib/docs/2007/november/tradoc_136958.pdf.
} 
As the SIA covered such a diverse range of states the initial phase noted the importance of the sectors studied to all ACP states. However, certain sectors regional grouping and sectors were singled out which would form the basis of the SIA analysis. These would be analyzed for those groupings in which a certain sector played a more prevalent role. Based on the initial phase the most important economic, environmental and social indicators associated with that sector were chosen for further analysis in the regional specific report. ${ }^{97}$ The lessons drawn for these sectors could later be applied for other negotiations for similar sectors. For example, for CARIFORM, the second phase study conducted for this region focused primarily on tourism as it was determined to be of key importance for the region in the initial phase based on trade in services that it attracted. ${ }^{98}$ For each study conducted the potential effect of the EPAs was modeled against a baseline model and policy recommendations were made on the basis of economic, environmental and social indicators studied.

Specifically, in relation to the CARIFORUM, the tourism study reviews the potential impacts of an EPA focusing on regional integration, trade with the EU, the potential economic (including investments), social and environmental impacts and provides specific policy recommendations. Here it should be noted that there was a specific public participation for this process which included presentations to civil society, trade negotiators from both the EU and CARIFORUM, stakeholders representing national and regional organizations, as well as communications available via the internet. ${ }^{99}$ This process was completed for every report.

The final SIA report, published in May 2007, aggregated the policy recommendations made in regional case studies and produced 12 recommendations focusing on regional integration, trade measures, measures to promote sustainability, and institutional mechanism and over sight including one on FDI. The Commission noted that this information was useful for the Commission, as well as "a wide range of other stakeholders." 100 Specifically, in relation to investment recommendation 6 stated that "[t]he EPAs should contribute to a stable climate for FDI and encourage FDI and regional investissement that support sustainability through, inter alia, including means of cooperation to achieve compliance with the enforcement of environmental and social

\footnotetext{
${ }^{97}$ Priority trade measures were chosen on the following criteria: The measure is a core component of the Cotonou Agreement; The measure is likely to be the subject of EPA negotiations with respect to liberalisation; The measure is one that could significantly affect trade in strategic sectors between the EU and the ACP; The measure is one where one might expect, a priori, that there may be important sustainability impacts. supra note 96 at 46.

${ }^{98}$ Price Waterhouse Coopers, Qualified Preliminary EU-ACP SIA of the EPAs: Phase One (Final Draft at p. vii., 25 available at http://trade.ec.europa.eu/doclib/docs/2005/january/tradoc_121195.pdf; Priority sectors were chosen based on the following criteria: The sector is significant from an economic, environmental and social perspective; The sector is significant in terms of trade flows in terms of both volume and value; The sector may be impacted by changes in the trade measures included in an EPA; The sector is one where one might expect that there will be potential impacts on sustainability at the local, regional or national level, or for specific actors. Final Report at 46.

${ }^{99}$ EPA Final Report, supra note 96 at 82.

${ }^{100}$ Position Paper Sustainability Impact Assessment of EU-ACP Economic Partnership Agreements, supra note 99 at p. 3 .
} 
regulations at the national level." 101 The Final Report noted that FDI is consider a positive "holding out the promise of, inter alia, job creation, industrial development, the transfer of skills and knowledge, state-of-the art technologies and management practices, and upgrading infrastructure." 102 The Final Report also noted concern about the quality and quantity of investment, but notes that the EPA may address such concerns through encouraging integration to address small market sizes of individual countries, and promote more stable investment environments by including rules for investment protection and transparency. ${ }^{103}$ The Final Report notes that such protections should ensure that FDI supports sustainable development such as a prohibition against lowering environmental and social standards to attract investment or against providing incentives to keep unsustainable investments. ${ }^{104}$

\section{Climate Change}

As a result of the unique nature of this report there is no real conclusions to the final impact of the report on climate change. In fact, in the final summary of key findings, policy recommendations and lessons learned of May 2007 there is no reference to either climate change or greenhouse gas. This stands in contrast to the CETA analysis which were climate change was a requirement for analysis in the Terms of Reference.

\section{Commission Response}

As a result of the nature of the EPAs and their focus on sustainable development many of the policy recommendations were not new to the Commission, but reinforced sustainable development in the negotiations. They also provided an avenue for public participation. Further, in its position paper the Commission noted that the EU will focus on "productive capacity building and integrate SIA results into in-country needs assessments processes" in response to a recommendation on development cooperation. ${ }^{105}$ Hence, the results of the SIA process also provided inputs for other development purposes.

Specifically, in relation to the recommendations provided stemming from the SIA the Commission agreed with seven out of the 12 policy recommendations and supported all policy recommendations made by the SIA process to varying degrees. Based on the development context of the EPAs, the Commission had already taken initiatives that supported many of the policy recommendations. In response to recommendation 6 the Commission noted that "a strong regional framework for investment, in both the services and the manufacturing sector, is essential for development." 106 The Commission also noted that "Commission Services believe that binding the current levels of liberalisation in sectors for which ACP countries wish to attract FDI will provide the kind of legal

\footnotetext{
${ }^{101}$ EPA Final Report, supra note 96 at 14

${ }^{102}$ ibid.at 14

${ }^{103}$ Ibid.at 15.

${ }^{104}$ ibid.at 15

${ }^{105}$ ibid at7.

${ }^{106}$ Position Paper, supra note 99 at 6.
} 
predictability that foreign investors seek before taking an investment decision." 107 The Commission also noted that it will assist in environmental and social regulations, however further detail is provided on that statement.. ${ }^{108}$ It should be highlighted that this contribution by the EPAs remains somewhat nebulous and unfortunately the Commission response does not shed much light on how such stability could be achieved.

\subsection{Critiques of SIAs with a Focus on a Sustainable Development and Climate Change}

As inputs into the negotiation process key improvements may be made to bolster the effectiveness of SIAs including legal requirements. Further information may also be sought to analysis the actual impact of the agreement once in force. This would be applicable to the existing SIAs assuming the EU continues its practice of SIAs for trade agreements and extends to FDI as a competence. Further, as demonstrated by the above case studies key environmental issues may be addressed through SIA's however, to ensure a robust analysis environmental issues such as sustainability, and climate it should be mandated generally, and may specific require an deeper investment-environment analysis. Such information may be useful as an input and may provide further clarity relating to environmental issues under a treaty in the event of an investment dispute.

On a structural level the lack of a clear legal requirement has been identified as one of the elements making this instrument less effective and somewhat ad hoc. While the methodology is relatively clear, a legal requirement could further strengthen the relevance and ultimately the effectiveness of SIAs. ${ }^{109}$ Without a clear legal mandate to commence SIAs and to ensure that recommendations from the SIAs are taken into account by negotiating teams and decision makers the SIA process remains somewhat of a paper tiger. SIAs may provide crucial economic, social and environmental information, however, without any requirement or accountability measure to ensure such information is considered, the intended effect of a SIA, as an input, may be mooted. Currently, the Commission is not bound by the recommendations and there is no obligation to take the recommendations into account. It could be said to constitute standing administrative practice in the Commission but as such could be subject to change. Further, there are no agreed upon standards for rejecting or accepting negative findings in an SIA report.

Second, in addition to substantive clarity on the legal requirement to perform an SIA, legal requirements may extend beyond the negotiations to require monitoring and verification requirements. While such assessments have been performed on certain trade agreements at present, and are mandatory for EU projects no such requirement exist in the EU for trade and investment agreements. As noted above, such frameworks have been mandated in trade agreements in other jurisdictions such as Canada. ${ }^{110}$ Moreover,

\footnotetext{
107 ibid.

${ }^{108}$ ibid at 5 and 6.

${ }^{109}$ Markus W. Gehring, \& Marie-Claire Cordonier Segger, supra note 30 at 212.

${ }^{110}$ See for example the Canada-Columbia FTA and Agreement concerning Annual Reports on Human Rights and Free Trade between Canada and the Republic of Colombia, Entry into Force 15 August 2011, Canada Treaty Series 2011/14..
} 
legislation on SIAs could also clarify the procedures for public participation, and for inter-agency cooperation. For example, a clear role could be identified for Directorate Generals that specialize in the environment, and human rights, whereas, for trade, currently negotiations are carried out by the Directorate General for trade alone.

Third, as highlighted though the case studies, consideration of sustainable development, and climate change can and should be augmented. Although the new SIA Handbook includes "in principle" an analysis of climate change and other environmental aspects, such an analysis is subject to the proportionality principle which guides the SIA process. The case studies demonstrate that the references can be relatively short and may lack specific analysis, for example of the impact on investment liberalization on climate or environmental policy space. While sustainable development considerations drive the SIA process, the analysis relating to key environmental factors may be increased. In this regard, the Terms of Reference (TOR) are crucial in scoping what "green activities" will be covered by an SIA. The CETA TOR, under the heading "tasks to be performed" specifically define the environmental impact to be analyzed. The CETA TOR defines environmental impact as "environmental impacts (pollutants, biodiversity and natural resources management, climate change, etc). ${ }^{111}$ Moreover, the contractor performing the SIA was specifically instructed to take into account an "external environmental cost analysis" which included an analysis on the

"impact of trade liberalisation on the most important types of greenhouse gas (GHG) emissions in the EU, in Canada and in the rest of the world. For this purpose, the Contractor should decompose the GHG effect into scale effects (as a result of increased output), composition effects (as a result of shifts in the relative weight of sectors) and possibly technique effects (as a result of productivity increases that can be attributed to the CETA). The analysis should cover at least the emissions of the most energy-intensive sectors and of primary energy producing sectors. It is expected that the environmental effects will be modelled within the CGE framework, so that on the one hand, environmental effects are linked to changes in production while on the other hand pollution costs are appropriately accounted for. The resulting domestic environmental impacts and global climate change impacts should be expressed in units of welfare as well as in million tons of $\mathrm{CO} 2$ (GHG equivalent) emissions". ${ }^{112}$

This required guidance ensured that climate issues were taken into account. A lack of defined instructions on what to include in the assessment left the Final Reports with effectively no guidance as how the agreement may help or hinder the green economies of all countries involved.

Effectuating such changes will strengthen the SIA process as an input into the negotiation to achieve results, while at the same time it can provide information on the result achieved. Providing actual data and analysis on the agreements on a pre-and post

${ }^{111}$ Final Report CETA, supra note 41 at p. 11.

${ }^{112} i$ bid at p. 12. 
basis may aid in easing the tension of trade and investment agreements. Specifically, in relation to investment a robust SIA process may help in debunking certain critiques relating to investment generally, and its impact on environmental and social issues. Moreover, a specific focus relating to the investment analysis of the SIA may play a role in the interpretation of an investment dispute.

\section{SIAs and the Interpretation of International Investment Agreement}

While SIAs may provide key inputs into the negotiation process to shape a treaty, SIAs also have the potential to play a part in the interpretation of the treaty itself in the event of an investment dispute through the rules of treaty interpretation. Given the increasing number of disputes related to environmental issues an SIA could provide interpretive guidance in this area depending on the case and the specific SIA and Commission response.

Specifically, the Commission response to an SIA can provide a clear position, or at least on the EU position on environmental issues. For example, in the EU-Andean position paper the Commission notes that there is not expected to be a significant impact on climate change while potentially having a significant impact in terms of deforestation and reduced biodiversity as a result of increased agriculture and timber industries. ${ }^{113} \mathrm{In}$ its policy recommendations the Commission response states that "[t]he policy space to adopt appropriate environmental protection measures, including on the basis of precautionary considerations, needs to be recognized and safeguarded." ${ }^{114}$ While many BITs do not contain any language in relation to environmental exceptions such statements could potentially be used to bolster a contextual argument on the basis of a treaty's preamble, object or purpose and may be increasingly useful in establishing clear environmental policy space under " $21{ }^{\text {st }}$ Century" trade and investment agreements such as CETA which directly address the relationship between trade, investment and the environment.

The recommendations provide in section 3 of this paper can further increase environmental considerations in the SIA report, and Commission response. Such increased considerations may directly impact the interpretive relevance of an SIA report and Commission response. After we explained the use and practice of SIAs as inputs in Section 2 and their limitations and potential critique in Section 3, this section discusses how SIA may influence an investment dispute as an interpretive aid.

\subsection{Treaty Interpretation and Supplementary Materials}

It is without question that any treaty interpretation issue in international law starts with the Vienna Convention on the Law of Treaties (VCLT). ${ }^{115}$ The VCLT sets out the

${ }^{113}$ Commission Service Position Paper on the Trade Sustainability Impact Assessment of the MultiParty Trade Agreement with Andean Countries, dated November 2010, supra note 72 at 5.

${ }^{114}$ ibid at 6.

${ }^{115}$ Vienna Convention on the Law of Treaties, 23 May 1969, United Nations, Treaty Series, vol. 1155, p. 331. 
applicable rules of international law for the interpretation of treaties. Articles 31 and 32 of the VCLT provide the basic framework for treaty interpretation and reflect customary international law. ${ }^{116}$

Article 31 of the VCLT requires a good faith interpretation to be given to the ordinary meaning of the terms of treaty, in their context, and in light of the object and purpose of the treaty and is drafted in mandatory language. Article 32 provides recourse to the preparatory work of the treaty and the circumstances of its conclusion, in order to confirm the meaning resulting from the application of article 31 , or to determine the meaning in situations where the meaning remains ambiguous or obscure or leads to a result that is manifestly absurd or unreasonable." 117

In light of this mandatory guidance provided textually in the VCLT it has become commonly understood and applied that to the extent that the wording of a provision is clear on its face, then there is no need for recourse to additional interpretation tools. ${ }^{118}$ Hence, Article 31 provides the primary means of interpretation and whereas as recourse to Article 32 should be limited.

In regards to investment agreements, SIA's and the corresponding Commission response would not form part of the treaty text. Further, it is unlikely that an SIA and Commission response are to be viewed as forming part of the context, as defined by VCLT Article 31(2). It is neither an agreement nor an instrument that is usually "accepted by the other parties as an instrument related to the treaty." "119 For example, in the WTO Gambling case, the Appellate Body stated that an Explanatory Note designed to "assist in the preparation of offers, requests, and national Schedules of commitments" and to ensure "comparable and unambiguous commitments" during GATT negotiations requested by the parties and drafted by the GATT Secretariat could not constitute context. The Appellant Body stated:

We do not accept, as the Panel appears to have done, that, simply by requesting the preparation and circulation of these documents and using them in preparing their offers, the parties in the negotiations have accepted them as agreements or instruments related to the treaty. Indeed, there are indications to the contrary. As the United States pointed out before the Panel, the United States and several other parties to the negotiations clearly stated, at the time W/120 was proposed, that, although Members were encouraged to follow the broad structure of W/120, it was never meant to bind Members to the CPC definitions, nor to any other "specific nomenclature", and that "the composition of the list was not a matter for negotiations". ${ }^{210}$ Similarly, the Explanatory Note that prefaces the Scheduling Guidelines itself appears to contradict the Panel in this regard, as it expressly provides that, although it is intended to assist "persons responsible for scheduling

\footnotetext{
116 See A.D. McNair, The Law of Treaties (Oxford: Clarendon Press, 1986) ("McNair (1986)"), at p. 465; Territorial Dispute (Libyan Arab Jamahiriya/Chad), Judgment, I.C.J. Reports 1994 ("Territorial Dispute"), at para. 41; Oil Platforms (Islamic Republic of Iran v. United States of America), Preliminary Objection, Judgment, I.C.J. Reports 1996,803 ("Oil Platforms - Preliminary Objection"), at para. 23.

${ }^{117}$ Vienna Convention on the Law of Treaties supra note 119, at art 32.

118 See Ulf Linderfalk, Is the Hierarchical Structure of Articles 31 and 32 of the Vienna Convention Real or Not? Interpreting the Rules of Interpretation, Netherlands International Law Review, 2007 p. 133-154.

${ }^{119}$ Vienna Convention on the Law of Treaties, supra note 119, at Art. 31(2).
} 
commitments", that assistance "should not be considered as an authoritative legal interpretation of the GATS." 120

Although an investment tribunal would not be bound by a WTO decision similar reasoning could be applied in the investment context as there would appear no overriding reason to depart from the reasoning provided in that case in a trade context. It is therefore unlikely that an SIA and Commission response would be considered under a more classic treaty interpretation approach.

Despite this common understanding of the application of the VCLT certain authors and tribunals have nevertheless advocated for or applied supplementary means of interpretation on equal footing as the interpretive process set out in Article 31 of the VCLT. Mortenson notes "it is often asserted that the VCLT relegates drafting history to a rigidly subsidiary role in treaty interpretation." ${ }^{121}$ He argues against such a rigid application in his 2013 article providing a great deal of detail on the intention of the drafters of the VCLT. Mortenson states that recourse to supplementary means was always intended by the drafters of the VCLT and therefore recourse to supplementary means of interpretation should always be available to a treaty interpretation. ${ }^{122}$ The hierarchy between Articles 31 and 32 has been challenged by certain prominent figures including Judge Stephen Schewbel, who draws on his significant experience in adjudicating international disputes to question the rigidity of interpretive framework. ${ }^{123}$ Judge Schewbel has stated:

.. Suppose as well that the parties to the treaty have argued and placed before the Court
the preparatory work of the treaty and the circumstances of its conclusion, as they
customarily do. Suppose that the Court has, as it invariably must, read, listened to and
weighed the evidence and arguments. May it bring to bear in arriving at it interpretation
of the treaty the travaux préparatoires only 'to confirm the meaning resulting from the
application of Article 31 '? Or may it bring to bear the travaux to correct- or indeed from
the outset to inform and influence-what otherwise would be its understanding of the
meaning of the treaty provisions at issue?

This alternative approach has been noted in some awards by international tribunals. For example, in the Bayview Award, when interpreting Article 1101 of the NAFTA, that Tribunal starts its analysis with the travaux préparatoires. ${ }^{125}$ This was noted by the Tribunal in Canadian Cattlemen Jurisdictional Award which stated "the Bayview Tribunal seems to start its respective examination with the travaux préparatoires... while, in the view of the present Tribunal, Article 31 VCLT calls for a

\footnotetext{
${ }^{120}$ United States- Measures Affecting the Cross-Border Supply of Gambling and Betting Services, AB-20051, 7 April 2005, WT/DS285/AB/R.

${ }^{121}$ Julian Mortenson, The Travaux of Travaux: Is the Vienna Convention Hostile to Drafting History, vol 107. American Journal of International Law 2013 at 780.

${ }^{122}$ ibid

${ }^{123}$ SM Schwbel, "May Prepartory Work be Used to Correct rather than Confirm the "clear" meaning of a Treaty Provision? in J. Makarczyk, ed. Theory of International Law at the Threshold of the 21st Century: Essays in Honour of Krzysztof Skubisszewski (The Hague, Kluwer Law International 1996) pp. 541-547.

${ }^{124}$ ibid at $542-543$.

${ }^{125}$ Bayview Irrigation District et al v. United Mexican States, Award, June 19, 2007 at para 95.
} 
primary examination of the ordinary meaning of the terms of the treaty in their context and in light of its object and purpose while the travaux may only be considered at a later stage as supplementary means of interpretation according to Article 32 VCLT." 126

If such an approach were to be used in a case where an SIA could be useful source for treaty interpretation one further argument that would need to be taken into account is whether an SIA is attributable to the respondent party. SIA's are prepared by external consultants and it could be argued that statements made by such external consultants are not attributable to the EU. On the other hand, strong arguments may be made for attributing SIA's to the EU based on the International Law Commission's Articles of State Responsibility. Similar arguments, given in a separate context, have recently been unanimously accepted in the Bilcon v. Canada Award, where the findings of an external panel conducting an environmental assessment under Canadian law where found to be attributable to Canada, through ILC Articles 4, 5 or and $11 .{ }^{127}$ In that case, the Tribunal noted, "In the present case, by contrast, the JRP was de jure an organ of Canada, equipped with a clear statutory role that included making formal and public recommendations to state authorities which the latter were obliged by law to consider and indeed ended up accepting." 128 As discussed above, the legislative framework for SIA is not place. Hence, any state responsibility argument would need to be considered in its specific context. However, the Bilcon Tribunal also noted "[e]ven if the JRP were not, by its nature, a part of the apparatus of the Government of Canada, the fact would remain that federal Canada and Nova Scotia both adopted its essential findings in arriving at the conclusion that the project should be denied approval under their environmental laws."129 Therefore, even though the SIA is performed by a third party, it can be adopted by EU as a subsequent act. Further, and most importantly, the Commission response to the SIA emanates directly from the Commission and not a third party.

In sum, it is unlikely that an SIA and Commission response would fall within the scope of the VCLT Article 31. However, certain tribunals have derogated from that approach, looking directly at supplementary sources. Even if such material does not fall within the scope of the VCLT, as noted by Judge Schewbel, if such material is presented in a dispute it still may sway a decision maker.

\subsection{SIA and the Commission Response as Supplementary Material}

What is clear is that through the VCLT it can be argued that an SIA and a corresponding response from the Commission could be used as a supplementary means of interpretation in the interpretation of an investment dispute. This could be done to confirm an understanding of the treaty achieved through the process set out in Article 31

\footnotetext{
${ }^{126}$ The Canadian Cattlemen for Fair Trade v. United States of America, Award on Jurisdiction, January 9, 2008, at para 219.

${ }^{127}$ William Ralph Clayton, William Richard Clayton, Douglas Clayton, Daniel Clayton, and Bilcon of Delaware Inc, v. Government of Canada, Award on Jurisdiction and Liability, 17 March 2015, PCA Case No. 2009-04.

128 ibid. at para 319.

129 ibid. at para 321 .
} 
or in the event of uncertainty or an absurd result it could aid in finding a meaning under a treaty.

For such an argument to be made a tribunal would need to determine its interpretive process through Articles 31 and 32, the admissibility of an SIA as part of a treaty's supplementary material and, if admissible, in turn its probative value. To be admissible a tribunal would have to find that the SIA and Commission response forms part of the supplementary material covered under Article 32 of the VCLT. Such material, while not set out by Article 32 in an exhaustive manner, includes "preparatory work of the treaty and the circumstances of its conclusion." ${ }^{130}$ Although Gardiner notes the meaning and scope of supplementary materials is controversial and in some instances remains uncertain an argument for SIAs forming part of either is possible. ${ }^{131}$

Further, any use of the SIA and Commission response would necessarily have to be case specific. However, given that SIA material is often overlooked this acts more as a suggestion to practitioners to, at a minimum, review an SIA and the Commission response for potential guidance relating to interpretation.

\section{Travaux Préparatoires}

The terms "travaux préparatoires" are not defined by the VCLT. ${ }^{132}$ Consequently international courts and tribunals have taken different views as to what constitutes travaux préparatoires. Authors such as McNair, in his seminal work on treaty interpretation, has defined 'prepartory work' as "an omnibus expression which is used rather loosely to indicate all documents, such as memoranda, minutes of conferences, and drafts of the treaty under negotiation." ${ }^{133}$ This is a broad statement as to what may be included as travaux and from such a definition it could be argued that this would include an SIA and its corresponding Commission response and is especially relevant where such material was shared with the negotiation partners.

Notably, the definition provided by McNair does not place any limitations on documents, such an SIA, which are unilaterally created. The International Court of Justice (ICJ) has similarly accepted certain unilateral material as forming part of the travaux préparatoires. In the Territorial Dispute involving Libyan Arab Jamahirya $v$. Chad the ICJ accepted a state's own summary of the negotiations treaty negotiations as forming part of the travaux. ${ }^{134}$ Here, the distinction may be made between a negotiation summary and unilateral input of one party. However, a summary produced by one party may not accurately reflect the positions taken the other.

\footnotetext{
${ }^{130}$ Yves Le Bouthillier, Article 32 Supplementary means of interpretation, in The Vienna Convention on the Law of Treaties: A Commentary Vol. 1, O. Corten and Pierre Klein eds. OUP 2011 at 851.

${ }^{131}$ Richard Gardiner, Treaty Interpretation, OUP, 2008 at 302.

${ }^{132}$ Yves Le Bouthillier, supra note 134 at 852.

${ }^{133}$ A.D. McNair, supra note 120 at 411.

${ }^{134}$ Territorial Dispute (Libyran Arab Jamahiriya v. Chad) ICJ Reports 1994 pp. 27-8 at para 55.
} 
In his commentary on treaty interpretation Gardiner, echoing Judge Schewbel's statement noted above, states that "courts and tribunals tend to seize on anything that looks helpful and they assess admissibility by applying the principle that clarificatory information must attest to a meaning which can be said to have been accepted (at least implicitly) by prospective parties." ${ }^{135}$ Such a pragmatic approach could be a useful strategy, especially when there is little other material to provide context to a treaty provision. This could be especially true where the SIA and Commission response are put forth as supporting evidence along with other material in support of an interpretive argument. Further, SIAs, while conducted unilaterally, often solicit the opinions of civil society groups both in and outside of Europe and are openly shared with EU negotiation partners and freely available on the EU's websites.

On the other hand, other tribunals have taken a more limited approach in defining the scope of travaux prepartoire. This distinction is generally based on documents that form part of the diplomatic negotiating history, and other documents that "explain the historical origin of the text." ${ }^{136}$ Based on this line of argument documents must stem from the negotiating process. In the Iron Rhine arbitration between Belgium and the Netherlands that tribunal decided that extracts of from extended negotiations did not form part of the travaux prepartoire under Article 32 of the Vienna Convention the extracts did not "serve the purpose of illuminating a common understanding as to the meaning' of the various provisions in issue." 137 This interpretation would seem to favor solely drafts of negotiation text, and formal exchanges within the negotiation context. Should such an approach be adopted it is unlikely that an SIA would be considered travaux.

Specifically, investment tribunals have occasionally resorted to travaux, however in many cases are limited from doing so due to a lack of availability or accessibility of the travaux. As noted by Dolzer and Schreuer the negotiating history of BITs are "typically not documented." "138 For example, the tribunal in Wena Hotela v. Egypt noted "[n]o documents, such as the travaux préparatoires, that might assist in interpreting Article 8(1) are available. Accordingly, the Tribunal can only rely upon third party commentary and its own interpretation of the provision to determine the intent of the United Kingdom and Egypt in consenting to bring disputes under ICSID jurisdiction." 139 Further, even if negotiation history exist, as experienced in the early NAFTA investment arbitrations such history may not be readily provided by the Parties. ${ }^{140}$ As noted by

\footnotetext{
135 Richard Gardiner, supra note 135 at 100.

136 Yves Le Bouthillier, supra note 134 at 853.

${ }^{137}$ Arbitration regarding the Iron Rhine Railway (Belgium/ Netherlands), Award of 24 May 2005 para 48.

${ }^{138}$ Rudolf Dolzer and Christopher Schreuer, Principles of International Investment Law, OUP, 2008 at p. 33.

${ }^{139}$ See, e.g., Wena Hotels v. Egypt (jurisdiction), at section IV.C: '[n]o documents, such as the travaux préparatoires, that might assist in interpreting Article 8(1) are 3available. Accordingly, the Tribunal can only rely upon third party commentary and its own interpretation of the provision to determine the intent of the United Kingdom and Egypt in consenting to bring disputes under ICSID jurisdiction.'

${ }^{140}$ See Pope \& Talbot v. Government of Canada letter from Lord Dervarid to the Parties, dated March 21, 2002, Methanex Corporation v. United States of America, Final Award on Jurisdiction and Merits, August 3, 2005 at PART II - Chapter H Methanex's Request for Documentary Disclosure by the USA: "The Travaux" for Articles 1101, 1102, 1105 and 2101 NAFTA .
} 
Fauchald ICSID investment tribunals "frequently resorted to preparatory work as the starting point for their analysis or as an essential argument, although it was most often used as a non-essential argument." 141 In this study of nearly 100 ICSID cases he noted that 25 out of 98 ICISD tribunals referred to the ICSID travaux, mainly in regards to jurisdictional issues. ${ }^{142}$ Moreover, he notes that 30 out of 98 cases refer to "unilateral state practice." 143 Hence, while in many cases travaux is not available, when it is available tribunals are not averse to using it.

An SIA and Commission response could then form part of the travaux préparatoires of a treaty. This will depend on whether a tribunal is prepared to accept a unilateral document- although in the case of an SIA such a document may have been shared and available to the other party, as well as may have taken invited submission from civil society of other treaty parties. Investment tribunals have accepted unilateral interpretive materials, however, this would be specific to a particular case and issue. Should an SIA not be considered as travaux préparatoires it may also be argued that it forms part of the circumstances of a treaties conclusion.

\section{Circumstances of the Treaties Conclusion}

While certain definitions of travaux may be restrictive, the "circumstances of the treaties conclusion" has been described as "encompassing all elements existing at the time of the conclusion of the treaty that can illuminate its meaning." 144 The definition considered in European Communities-Custom Classification of Frozen Boneless Chicken Cuts where the WTO Appellate Body set out the key objective factors to determine relevant circumstances. The factors included "the type of event, document, or instrument and its legal nature; temporal relation of the circumstance to the conclusion of the treaty; actual knowledge or mere access to a published act or instrument; subject matter of the document, instrument, or event in relation to the treaty provision to be interpreted; and whether or how it was used or influenced the negotiations of the treaty." 145

Further and possibly most importantly the Appellate Body noted that unilateral acts may form part of the circumstances of the conclusion of the treaty and add to its interpretation. Here, the Appellate Body noted "not only "multilateral" sources, but also "unilateral" acts, instruments, or statements of individual negotiating parties may be useful in ascertaining "the reality of the situation which the parties wished to regulate by means

${ }^{141}$ Ole Kristian Fauchald, The Legal Reasoning of ICSID Tribunals- An Empirical Analysis, The European Journal of International Law, Vol 19 no. 2, 2008, at 350.

${ }^{142}$ Fauchald, at 349-350.

${ }^{143}$ Fauchald, at 347.

${ }^{144}$ Yves Le Bouthillier, supra note 117 at 859 . A similar definition is provided by Gardiner. Richard Gardiner, Treaty Interpretation, OUP, 2008 at 343. Nevertheless, as noted in Territorial Questions between Qatar and Bahrain not all circumstances necessarily provided supplementary elements of interpretation. Territorial Questions between Qatar and Bahrain, Jurisdiction and Admissibility, ICJ Reports 1995 at p 23 , p. 23.

${ }^{145}$ European Communities-Custom Classification of Frozen Boneless Chicken Cuts, 12 September 2005, Wf/DS286/AB/R, para. 291. 
of the treaty" and, ultimately, for discerning the common intentions of the parties." ${ }^{\text {"146 This }}$ principle was similarly held in Chilean Price Band System where a WTO Panel found admissible the reports of various agricultural committees established by participants in the 1947 GATT. ${ }^{147}$ Here, the panel noted that "strictly speaking [the reports are] not of the preparatory work" but found them admissible under Article 32 of the Vienna Convention as they formed part of the circumstances of the conclusion of the treaty. ${ }^{148}$ While investment treaty tribunals do not uniformly follow WTO jurisprudence, this passage, referring to a general definition in international law is persuasive and has considerable weight. Here, again, there seems little reason to distinguish trade determinations from investment in such a case.

Additionally, in the Oil Platforms case, the ICJ admitted unilaterally sourced material. In this case, when interpreting a provision of a US-Iranian treaty on of Amity, Economic Relations and Consular Rights the judges of the ICJ found admissible a US State Department memorandum providing an explanation of the same treaty provision in a different treaty. ${ }^{149}$ While not being the only source material that judges reviewed in coming to their conclusion it stands that such information was admitted.

While arguments restricting the use of unilateral material could be brought in the investment context for materials under this heading, given its broad scope and previous decisions allowing such material it appears unlikely that such material would be inadmissible. However, the weight to be given to such material could rightfully be argued. Again, this would be context specific.

Given that an SIA and specifically the Commission response is a contemporaneous document to the treaty negotiations and conclusions, that it provides a direct input into negotiations with first hand research on the impacts of a treaty and direct positions based on that information a strong argument may be made for the admissibility of an SIA and Commission response as a document relevant to the conclusion of the treaty. The probative value will depend on the specific question at hand and the corresponding information in the SIA and Commission response.

\section{Conclusion}

The SIA process can act as a bridge between trade, investment and environmental concerns and has the potential to influence investment on a continual basis. As an input it can allow negotiators to build better investment treaties by increasing the knowledge of the potential impacts of an investment treaty or chapter. This can include both positive and negative impacts. Further, monitoring can provide information relating to the actual impact of the treaty. As an interpretive aid an SIA has the potential to contribute to the interpretation of an investment treaty in the event of an investment dispute. A specific

\footnotetext{
${ }^{146}$ ibid at para 289.

${ }^{147}$ Chile-Price Band System and Safeguard Measers Relating to Certain Agricultural Products WT/DS207/R, 3 May 2002 para 7.35-7-36.

${ }^{148}$ ibid at para 7.35 .

${ }^{149}$ Anglo-Iranian Oil Company Case (Preliminary Objections) (1952) ICJ Reports 93 at 106-7.
} 
focus on sustainable development and climate change in the SIA increase the awareness of the trade, investment, and environment nexus. Further, in focusing SIA's on sustainable development and climate change the EU may support its overall goal of sustainable development ${ }^{150}$ as well as the specific objectives of the EU's investment competence. $^{151}$

That being said, in terms of the SIA as an input in relation to sustainable development, and climate change key changes can be made to the EU SIA process which can further these objectives specifically as an input and potential as an interpretive aid. These include adopting a legal framework for SIAs for investment agreements. This framework would provide additional clarity. The additions to the current SIA process which would increase its effectiveness such as requirements for negotiators to take SIA inputs into account, the ability of inter-departmental information sharing, and monitoring and verification steps to ensure that the predicted outcomes of a treaty are in line with expectations. Further, when implementing an SIA it is crucial to sufficiently scope SIAs to effectively cover and provide sufficient detail on key issues. Notably, as demonstrated in the case studies, there was a variance in how climate change was considered through the SIAs. One solution would be to include such terms directly in the Terms of Reference provided to external consultants. Direct requirements to specifically provide analysis relating to sustainable development and climate change, and specifically how it relates to investment will improve the SIA process and may specifically further the appreciation of the environmental effects of treaties. Such further steps may also make SIA's and Commission responses more relevant to treaty interpretation of environmental issues, especially since may investment treaties do not contain specific environmental exceptions or provisions.

Through the rules of international treaty interpretation an SIA and Commission response document could form part of an interpretation of provisions of an investment treaty or chapter as a supplementary means of interpretation,. In this regard, the Vienna Convention is clear that in the event that text of a treaty is clear there is no need to resort to supplementary interpretive means. However, it may be used to confirm a meaning or provide meaning in the event of uncertainty. Here, the Commission response, depending on its detail, may provide clarity in environmental issues. Such an approach could find increasing relevance in new "21st Century" treaties which pay increasingly more attention to the investment and environment nexus.

\footnotetext{
${ }^{150}$ European Union: Council of the European Union, Treaty of Amsterdam Amending the Treaty on European Union, The Treaties Establishing the European Communities and Related Acts, 10 November 1997 at art. 2, 3; European Union, Treaty on European Union (Consolidated Version), Treaty of Maastricht, 7 February 1992, Official Journal of the European Communities C 325/5; 24December 2002 at article 3.3, 21.2 available at http://eur-lex.europa.eu/legal-content/EN/TXT/PDF/?uri=CEL EX:12012M/TXT\&from=EN.

${ }^{151}$ Communication from the Commission to the Council, the European Parliament, The European Economic and Social Committee and the Committee of the Regions: Towards a comprehensive European international investment policy, 7 July, 2010 COM (2010) 343 available at http://trade.ec.europa.eu/doclib/docs/2011/may/tradoc_147884.pdf.
} 
The SIA process can provide ex-ante inputs into an investment treaty to shape the treaty while also having the potential to effect its interpretation. If further focused on sustainable development and climate change this may positively affect the relation between investment and environment. In this light SIAs can aid in constructively working any tension between investment and environment to provide an investment and environment framework that is more mutually supportive and furthers sustainable development. 